\title{
Investigation on the Problems Faced by the Farmers in Obtaining and Repayment of Agricultural Credit in Karaikal District, India
}

\author{
R. Subramanian ${ }^{1} *$ and Sunil Shivananjappa ${ }^{2}$ \\ ${ }^{1}$ Pandit Jawaharlal Nehru College of Agriculture and Research Institute, Karaikal, India \\ ${ }^{2}$ University of Agriculture Science, Bangalore, College of Agriculture, Hassan, India \\ *Corresponding author
}

\section{Keywords}

Agricultural credits,

Banking community,

Credit obtaining and

repayment problems.

Article Info

Accepted:

28 September 2017

Available Online:

10 November 2017

\section{A B S T R A C T}

Agriculture remains the mainstay of Indian economy. The major contribution for the Indian agriculture is supported by the marginal and small farmers. Agriculture is most important for the sustainable development. Until 1935, the major sources of funds for the farmers were the professional money lenders. Due to their unduly high rate of interest, farmers were heavily burdened with debts, which lead to the riots and even miserable suicides. Later, Government of India has undertaken those issues and established agricultural credit policy through various institutional agencies. Still there exists lack of rapport between the bankers and the farmers both in obtaining the crop loans as well as in repaying. As a result, small and marginal farmers were trapped in vicious cycle of poverty, i.e., low savings $\rightarrow$ low investments $\rightarrow$ low returns. The present study was carried out with the main objective of studying the impact of institutional agricultural finance among the farmers. The specific objectives of this study were to analyse the extent of agricultural fiancé obtained by the farmers and its repayment. The data collected through personal interview were analysed by the Garett scoring technique. The result indicated that the major problems faced by the farmers in obtaining the institutional credit were the nonavailability of loan in time, the procedure for obtaining the credit was more expensive, inadequate amount of loan sanctioned against the actual requirement, the transport cost and document expenses. The farmers listed out the problems they faced in repaying the credit were - crop failure, failure of monsoon, expectation of waiving of loans by the government, lower yield, and increase in the cost of cultivation, decrease in the market value of the harvested produce. Thus this study concluded that the agricultural credit needs of famers are increasing with the increase in cost of cultivation. The Government should update its credit policy, to meet out the credit needs of the farmers.

\section{Introduction}

Agriculture remains the mainstay of the Indian economy. It is the major source of livelihood for 80 per cent of the rural population and supports 72 per cent of the work force (Sudha Narayanan, 2015). Diversification of farm production activities with animal husbandry, fisheries and horticulture would increase the income of the marginal and small farmers and landless agricultural labourers in tune with the objective of growth with social justice. The economic development of a developing country like India depends much on the development of agriculture (Sidhu and Sucha Singh, 2006). However, the development of agriculture depends on the technology which, 
in turn, depends on the massive use of capital (Edward Njuguna et al., 2015). Of late, capital has become one of the crucial factors in determining the kinds, quantity and quality of agricultural production of a country.

Hence the tempo of agricultural development could be accelerated through the provision of adequate credit to the farmers at the right time, at the right place and through the right institution (Ikani et al., 2013). In India, various agencies like indigenous moneylenders, commercial banks and cooperative organisations meet the credit requirements of farmers (Coman et al., 2014). Credit serves a useful purpose only when used wisely for production purpose. Credit may be easily compared to a sharp edged knife, proper utilisation of it usually generated higher productivity and thereby more prosperity, and whereas its mis utilisation derives the borrowers of the extra income they could have earned by using it for the production purposes as well as retards the flow of credit (Sudha Narayanan, 2015).

\section{Agricultural credit policy}

Professional money lenders were the only source of credit to agriculture till 1935. As a result, the farmers were heavily burdened with debts and many of them perpetuated debts (Parvathamma, 2016). A powerful alternative agency can in the name of institutional agencies for providing credit to the farming community with reasonable rated of interest. Farm finance has become an important input due to the advent of capital intensive agricultural technologies (Anwarul hoda, 2015). Farmers require capital in order to enhance the productivities of various farm sources. The government of India has initiated several policy measures to improve the accessibility of farmers to the institutional sources of the credits. The emphasis of these policies has been on progressive institutionalization for providing timely and adequate credit support

\section{Core theme of research}

Taking consideration of the importance of agricultural credits and the lack of rapport between the bankers and the farming community, the research was oriented towards the study of credit availed by the farmers and also the performance of institutional agencies in providing credits to farmers of Karaikal and finally the problems faced by the farmers in obtaining and repayment of credit.

\section{Scope and importance}

The study focuses attention on increasing the scope for a healthy growth of institutional credit to improve the financial management of the farms. Thus, the findings will be useful to the policy makers to plan future programmes and the findings will also be useful to the farmers to know the ways for effective use of credit and the importance of a healthy financial discipline in repayment of credit

\section{Selection of the study area}

The union territory of Puducherry consists of four districts, viz., Puducherry, Karaikal, Mahe and Yanam. The study was undertaken in Karaikal district.

\section{Sampling procedure}

A multi stage ratified random sampling techniques was adopted with Karaikal district as the Universe, the communes as the first stage unit, the villages as the second stage unit and the farmers who borrowed loans fromthe institutional agencies as the ultimate unit of the sample. Karaikal Districts has six communes viz., Kottucherry, Nedungadu, Thirunallar, Neravy, Karaikal and 
Thirumalarajan-pattinam. Nedunagdu and Thirunallar commune were selected for the research purpose.

\section{Sample size}

The total number of respondents was fixed as 120 at the rate of 60 per commune. The samples of 60 farmers from each of these two communes were distributed among the six villages in probability proportion. The respondents were selected at random in each village. The sample farmers under each category were selected in proportion to their respective total population, the selected villages with the sample respondents in each of the selected villages are furnished in Table 1.

\section{Collection of data}

The data were collected through personal interview with the selected respondents. The interview schedules were presented in the study area and finalised. Though the farmers did not maintain any records of their farm business activities, they gave the required data and information regarding farming conditions and cultural practises by recalling from their memories to a satisfactory level. Detailed information were also collected on the the extent of agricultural loans obtained by different categories of farmers and the problems faced by the farmers in obtaining the institutional credit and the repayment.

\section{Tools of analysis}

\section{Scoring technique}

To study the problems faced by the farmers in obtaining institutional credit, scoring technique was adopted, as suggested by Garett for converting the ranks into scores, when the preference of a particular problem different from respondent to respondent. The conversion method was as follows:
As a first step the per cent position of each rank was found out by the given formula

Per cent position $=\frac{100-(\mathrm{Rij}-0.5)}{\mathrm{Nj}}$

Where

Rij $=$ Rank given for $i^{\text {th }}$ item by the $j^{\text {th }}$ individual

$\mathrm{Ni}=$ Numbers of items ranked by $\mathrm{j}^{\text {th }}$ individual

The per cent position was then converted into scores by referring to the table given by Garett. Following this procedure, order of merit given by each of the respondents as the problems in getting loans from institutional agencies was converted into scores.

Then for each reason, the scores of individual respondents were added together and divided by the total number of respondents were added. These mean scores for all reasons were arranged in descending order and ranks were given. By this method, the accuracy in determining the preference was obtained.

\section{Results and Discussion}

\section{Problems in obtaining institutional credit}

The problems of agricultural finance are manifold and complex. Administration of farm finance bristles with problems both at organisational and functional levels. The beneficiaries obtained credit from institutional agencies for various purposes. However, some of them were confronted with certain problems in this process. However, some of them were confronted with certain problems in this process. The study has shown the various problems in obtaining the institutional credit, which is presented in table 2 . From the table 2 , it could be seen that nine problems 
were identified by the respondents. Out of those nine, the non-availability of loan in appropriate time was ranked as the foremost one which caused inconvenience to the beneficiaries in obtaining the credit.

The expenses incurred in obtaining the documents essential for obtaining the loan were ranked second. The beneficiaries stated that they have to incur expenses in obtaining the same documents for each year. The essential security was ranked third. It is informed that the production of the collateral security each and every time was the problem in obtaining the credit. The expensive procedure in obtaining the institutional credit was ranked fourth. The beneficiaries stated that the procedure for obtaining the credit was more expensive. The delayed disbursement of institutional credit has toiled them a lot and it sometimes made to search the credit from other sources, ranked fifth. The complicated formalities in obtaining the credit, inadequate amount of loan sanctioned against the actual requirements were ranked sixth and seventh respectively by the beneficiaries. The corruption like officials getting bribe and the higher rate of interest for the loan has been ranked eighth and ninth respectively

Table.1 Sample size

\begin{tabular}{|l|l|c|c|c|c|}
\hline \multirow{2}{*}{ Sl.no } & \multirow{2}{*}{ Village } & \multicolumn{3}{|c|}{ Category of farmers } & \multirow{2}{*}{ Total } \\
\cline { 3 - 5 } & & Marginal & Small & Big & \\
\hline 1 & Keezhaponbathy & 7 & 7 & 6 & 20 \\
\hline 2 & Kurumbakaram & 7 & 6 & 7 & 20 \\
\hline 3 & Nallathur & 7 & 6 & 7 & 20 \\
\hline 4 & Agaramankudy & 7 & 7 & 6 & 20 \\
\hline 5 & Ambagarathur & 6 & 7 & 7 & 20 \\
\hline 6 & Surakudy & 6 & 7 & 7 & 20 \\
\hline & Total & $\mathbf{4 0}$ & $\mathbf{4 0}$ & $\mathbf{4 0}$ & $\mathbf{1 2 0}$ \\
\hline
\end{tabular}

Table.2 Problems in obtaining institutional credit

\begin{tabular}{|l|c|c|c|}
\hline \multicolumn{1}{|c|}{ Problems faced } & No. of persons ranked & Score & Rank \\
\hline Not availability in time & 35 & 84 & 1 \\
\hline Document expense & 22 & 80 & 3 \\
\hline Collateral security & 15 & 77 & 4 \\
\hline Expensive procedure & 14 & 76 & 5 \\
\hline Delayed disbursement & 13 & 75 & 6 \\
\hline Complicated formalities & 9 & 74 & 7 \\
\hline Inadequate credit & 7 & 73 & 8 \\
\hline Corruption & 3 & 62 & 9 \\
\hline Higher rate of interest & 2 & 60 & \\
\hline
\end{tabular}


Table.3 Problems in repayment of credit

\begin{tabular}{|l|c|c|c|}
\hline Problems in repayment & No. of persons ranked & Score & Rank \\
\hline Crop failure & 55 & 60 & 1 \\
\hline Failure of monsoon & 26 & 50 & 2 \\
\hline Non-waiving of loan & 11 & 49 & 3 \\
\hline Lower yield & 7 & 48 & 4 \\
\hline Flood & 6 & 47 & 5 \\
\hline Increase in input cost & 5 & 46 & 6 \\
\hline Family size & 4 & 45 & 7 \\
\hline $\begin{array}{l}\text { Lower value for the produce } \\
\text { produced }\end{array}$ & 3 & 42 & 8 \\
\hline Higher rate of interest & 2 & 41 & 9 \\
\hline Willful default & 1 & 30 & 10 \\
\hline
\end{tabular}

\section{Problems in repayment of credit}

As the beneficiaries faced problems in obtaining the institutional credit, they also had problems in the repayment also. The expressed ten types of problems in the repayment of the loan amount they borrowed from the various institutions are presented in table 3 .

From the table 3, it could be observed that the crop failure was ranked as the foremost reason for the non-repayment of the institutional credit obtained by the sample farmers. Failure of monsoon was ranked second. The beneficiaries expressed that the monsoon failure played the tragedy in their life many time. The expectation of waiving of loans by the government has been ranked third by the beneficiaries and the lower yield has been ranked fourth by the sample farmers.

The unforeseen flood at the same time of harvest has been ranked fifth by the beneficiaries. Steady increase in the cost of inputs make them to borrow from other sources, also leads them to be as a defaulter of the loan from the institutional agencies is ranked agencies is ranked sixth by the sample farmers The family size of the farmers and the lower price for the harvested produce are ranked as seventh and eight respectively by the farmers as the reasons for problem in repayment. Higher rate of interest was given as a reason by two farmers which ranks ninth and some of the farmers are acting as the wilful defaulters is ranked last i.e. tenth. The study concluded that nine problems were identified by the respondents. Out of these nine, the nonavailability of loan in appropriate time was ranked as the foremost one which caused inconvenient to the beneficiaries in obtaining the credit. The expenses incurred in obtaining the documents essential for obtaining the loan were ranked second. The beneficiaries stated that they have to incur expenses in obtaining the same documents for each year. The collateral security was ranked third. It is informed that the production of the collateral security each and every time was the problem in obtaining the credit. The expensive procedure in obtaining the institutional credit was ranked fourth. The beneficiaries' stated that the procedure for obtaining the credit was more expensive. The delayed disbursement of institutional credit has toiled them a lot and it sometimes made them to search the credit form sources, ranked fifth the complicated formalities in obtaining the credit, inadequate amount of loan sanctioned against the actual requirement were ranked sixth and seventh respectively by the beneficiaries. The corruption like officials getting bribe and the higher rate of interest for the loan has been ranked eight and ninth respectively.

As the beneficiaries faced problems in obtaining the institutional credit, they also had problems 
in the repayment also. They expressed that the crop failure was ranked as the foremost reason for the crop failure was ranked as the foremost reason for the non-repayment of the institutional credit obtained by the sample farmers. Failure of monsoon failure played the tragedy in their life many tome. The expectation of waiving of loans by the government has been ranked fourth by the sample farmers. The unforeseen flood at the time of harvest has been ranked fifth by the beneficiaries. Steady increase in the cost of inputs make them to borrow from other sources, also leads them to be as a defaulter of the loan from the institutional agencies is ranked sixth by the sample farmers. The family size of the farmers and the lower price for the harvested produce are ranked as seventh and eight respectively $\mathrm{y}$ the farmers as the reasons for problem in repayment. Higher rate of interest was given as reason by two farmers which ranks ninth and some of the farmers are acting as the wilful defaulters is ranked i.e., tenth.

\section{Policy implications and future scope}

This study has revealed that the borrowers have to incur costs in getting credit from the institutional agencies. They had also encountered some difficulties in getting the required credit at that time. Both these problems would be counterproductive in the long run. Hence, efforts should be taken to eliminate the illegal costs in obtaining credit. Steps should also be taken to make available the required credit in time and in adequate amount.

\section{References}

Anjani Kumar Ashok K. Mishra Sunil Saroj. Institutional versus Noninstitutional Credit to Agricultural Households in
India Evidence on Impact from a National Farmers' Survey. IFPRI Discussion Paper 01614. March 2017.

Anwarul Hoda, Prerna Terway. Credit Policy for Agriculture in India - An Evaluation. Indian council for research on international economic relations. June 2015

Comlan Hervé Sossou, Freddy Noma. Rural Credit and Farms Efficiency: Modelling Farmers Credit.Allocation Decisions, Evidences from Benin. Hindawi Publishing Corporation. Economics Research International Volume 2014, Article ID 309352, 8 pages

Edward Njuguna. Formal Conditions that Affect Agricultural Credit Supply to Small scale Farmers in Rural Kenya: Case Study for Kiambu County. http://dx.doi.org/10. 1155/2014/309352

http://www.igidr.ac.in/pdf/publication/WP2015-01.pdf

IKANI, Daniel Idoko, B. An Impact Assessment of Agricultural Credit on Rural Farmers in Nigeria. Research Journal of Finance and Accounting. Vol.4, No.18, 2013

Parvathamma. G. L. Farmers Suicide and Response of the Government in India -An Analysis. IOSR Journal of Economics and Finance (IOSR-JEF) Volume 7, Issue 3. Ver. I (2016), PP 01-06

Sidhu R.S., and Sucha Singh Gill. Agricultural Credit and Indebtedness in India: Some Issues. Ind. Jn. of Agri. Econ..Vol. 61, No. 1, Jan.-March 2006

Sudha Narayanan. The Productivity of Agricultural Credit in India. Indira Gandhi Institute of Development Research, Mumbai January 2015.

\section{How to cite this article:}

Subramanian, R. and Sunil Shivananjappa. 2017. Investigation on the Problems Faced by the Farmers in Obtaining and Repayment of Agricultural Credit in Karaikal District, India. Int.J.Curr.Microbiol.App.Sci. 6(11): 3966-3971. doi: https://doi.org/10.20546/ijcmas.2017.611.463 